\title{
PENGEMBANGAN PETUNJUK PRAKTIKUM GELOMBANG DAN BUNYI BERBANTUAN KEARIFAN LOKAL UNTUK MENINGKATKAN MOTIVASI BELAJAR SISWA KELAS XI
}

\author{
Marha1, Islahudin' ${ }^{2}$, Linda Sekar Utami ${ }^{3}$ \\ 1Pendidikan Fisika, Universitas Muhammadiyah Mataram, marhapian14@gmail.com \\ 2Pendidikan Fisika, Universitas Muhammadiyah Mataram, islahudin.ntb@gmail.com \\ 3Pendidikan Fisika, Universitas Muhammadiyah Mataram, Lindasekarutami@gmail.com
}

\section{INFO ARTIKEL}

\section{Riwayat Artikel:}

Diterima: 12-03-2018

Disetujui: 01-04-2018

\section{Kata Kunci:}

Petunjuk Pratikum Motivasi Belajar

\begin{abstract}
ABSTRAK
Abstrak: Tujuan dari penelitian ini untuk mengembangkan buku petunjuk pratikum pada pokok bahasan gelombang dan bunyi untuk meningkatkan motivasi siswa. Penelitian ini menggunakan metode research and development (R \& D). Sebagai subjek dalam penelitian ini adalah siswa MAN 2 Model Mataram Kelas XI. Model pengembangan yang digunakan adalah Dick \& Carey yang terdiri dari 10 langkah yang harus diikuti untuk menghasilkan produk berupa buku petunjuk pratikum. Data diperoleh melalui wawancara, angket dan dokumentasi. Teknik analisis data yang digunakan adalah deskriptif kualitatif untuk mengukur motivasi belajar siswa.
\end{abstract}

\begin{abstract}
The purpose of this study was to develop a pratikum manual on the subject of waves and sounds to improve student motivation. This research uses research and development (R \& D) method. As subject in this research is student MAN 2 Model Mataram Class XI. The development model used is Dick \& Carey which consists of 10 steps that must be followed to produce the product in the form of manual pratikum. Data obtained through interviews, questionnaires and documentation. Data analysis technique used is descriptive qualitative to measure student's learning motivation.
\end{abstract}

\section{A. LATAR BELAKANG}

Pendidikan merupakan kebutuhan utama dalam kehidupan manusia. Sejak lahir orang tua sudah membekali pendidikan kepada anaknya. Setelah anak tumbuh dan berkembang, pembelajaran kepada anak diberikan melalui jenjang pendidikan sekolah dasar, sekolah menengah hingga perguruan tinggi. Pendidikan di sekolah terdiri dari mata pelajaran yang mengikuti kurikulum yang berlaku. Salah satu mata pelajaran tersebut yaitu fisika yang merupakan cabang ilmu dari IPA. Fisika merupakan salah satu ilmu yang membutuhkan sarana dan prasarana dalam pembelajaran. Fisika tersebut akan lebih bermakna apabila terdapat kesinambungan antara materi mata pelajaran dengan aktivitas kehidupan sehari-hari di lingkungan tempat tinggal siswa yang digunakan sebagai sarana belajar. Hal ini dapat diperoleh melalui keterkaitan penerapan materi fisika dengan potensi lokal daerah tersebut. Namun dalam sarana belajar dilingkungan tempat tinggal siswa khususnya untuk SMA belum banyak kearifan lokal dimanfaatkan dalam pembelajaran fisika. Umumnya guru menggunakan potensi lingkungan sebatas sebagai apersepsi, belum sampai pembahasan materi fisika pada kearifan lokal yang lebih mendalam dan kunjungan langsung ke lokasi siswa belum tentu paham dengan tujuan pembelajaran yang akan dicapai.

Kearifan lokal merupakan ciri khas suatu daerah atau wilayah tertentu yang memiliki nilai kebudayaan, berkembang dalam lingkup sosial dari generasi ke generasi berikutnya. Pembelajaran berbantuan kearifan lokal dilandaskan pada pengakuan terhadap budaya sebagai bagian yang fundamental bagi pendidikan sebagai ekspresi dari komunikasi suatu gagasan dan perkembangan pengetahuan. Pembelajaran berbantuan budaya lokal sebagai salah satu pembelajaran inovatif perlu terus dikembangkan. Itegrasi budaya lokal dalam pembelajaran fisika menjadikan pembelajaran lebih bermakna bagi siswa (Supratman, dkk, 2016:82)

Selain itu kearifan lokal sebagai salah satu hal yang perlu dilestarikan, artinya perlu dijaga, dilindungi, dan dilestarikan agar tidak punah. Berdasarkan hasil observasi pada saat Praktik Pengalaman Lapangan (PPL) di MAN 2 Model Mataram, diperoleh bahwa pemanfaatan lingkungan kurang optimal di dalam pembelajarn IPA dan medial lingkungan hanya untuk materi tertentu saja. Lingkungan hanya sebagai objek dalam pembelajaran tanpa mengetahui nilai-nilai budaya yang terkandung dalam pembelajaran IPA.

Petunjuk pratikum adalah pedoman pelaksanaan pratikum yang berisi tata cara persiapan, pelaksanaan, 
analisis data dan pelaporan. Dengan demikain buku petunjuk pratikum merupakan suatu buku yang berisi pengarahan yang bertujuan untuk member tahu dalam melaksanakan kegiatan pratikum.

Berdasarkan paparan di atas pembelajaran fisika dengan memanfaatkan kearifan lokal dapat membawa peserta didik memperoleh pengalaman belajar secara langsung dengan situasi alam sekitarnya guna meningkatkan hasil belajar sains peserta didik, sehingga peneliti bermaksud untuk melakukan penelitian yang berjudul "Pengembangan Buku petunjuk praktikum Gelombang Dan Bunyi Berbantuan Kearifan Lokal Untuk Meningkatkan Motivasi Belajar Siswa Kelas XI". Dengan tujuan supaya peserta didik menghasilkan petunjuk peraktikum berorientasi kearifan lokal yang valid dan meningkatkan hasil belajar peserta didik melalui proses pembelajaran berorientasi kearifan lokal.

\section{B. METODE PENELITIAN}

Jenis penelitian ini adalah penelitian pengembangan (Reseach \& Development). Reseach \& Development adalah metode penelitian yang digunakan untuk menghasilkan produk (Sugiyono, 2014: 297). Produk yang dihasilkan dalam penelitian pengembangan ini adalah petunjuk praktikum berbentuk buku petunjuk praktikum. Penelitian pengembangan merupakan kegiatan mengembangkan suatu produk baru atau menyempurnakan produk yang telah ada.

Desain penelitian ini menggunakan satu kelas sampel sebagai kelas uji coba (One Group Pre- Test and Post-test Design). Teknik pengumpulan data pada penelitian ini adalah angket dan dokumentasi. Angket digunakan untuk mengumpulkan data tentang kelayakan buku petunjuk praktikum yang dibuat dan akan dijawab oleh responden yang terkait pembelajaran antara lain: ahli materi, ahli media dan siswa sebagai pengguna buku petunjuk praktikum berbantuan kearifan lokal. Penelitian ini telah dilaksakan di MAN 2 Model Mataram, melibatkan siswa kelas XI. Penelitian ini telah dilaksanakan pada bulan Agustus sampai September 2017 pada Siswa MAN 2 Model Mataram Kelas XI.

Model pengembangan yang digunakan dalam penelitian ini adalah Dick \& Cary yaitu menggariskan langkah-langkah untuk menghasilkan produk berupa buku petunjuk praktikum berbantuan kearifan lokal yaitu: (1) Mendefinisikan tujuan untuk produk, (2) Analisis instruksional, (3) Mengidentifikasi keterampilan dan sikap siswa, (4) Menerjemahkan kebutuhan dan tujuan pembelajaran, (5) Instrumen penilaian dikembangkan, (6) Strategi pembelajaran dikembangkan, (7) Mengembangkan dan melibatkan materi pembelajaran (8) Merencanakan dan mengembangkan evaluasi vormatif (9) Melakukan revisi terhadap program pembelajaran dan (10) mengembangkan dan merancang evaluasi sumatif (Emzir, 2014: 276).

\section{Langkah-langkah Penelitian Pengembangan}

Menurut Sugiyono (2014:298-311) langkah-langkah penelitian dan pengembangan, yakni :
1. Potensi dan masalah
2. Desain produk
3. Validasi desain
4. Perbaikan desain
5. Uji coba produk
6. Revisi produk
7. Uji coba pemakaian
8. Revisi produk
9. Pembuatan produk massal

Penelitian ini dilakukan sampai pada tahap uji coba produk karena keterbatasan waktu dan dana. Media dikatakan valid apabila telah divalidasi oleh ahli dan diuji kefektifannya oleh peneliti dengan adanya peningkatan motivasi belajar pada diri masing-masing siswa.

\section{Instrumen Pengumpulan Data}

Instrument penelitian digunakan untuk mengukur nilai variabel yang akan diteliti (Sugiyono, 2014: 92). Secara spesifikasi fenomena yang terjadi disebut variable penelitian. Instrument yang digunakan dalam penelitian ini lembar angket motivasi (kuisioner). Kuisioner merupakan teknik pengumpulan data yang dilakukan dengan cara memberi seperangkat pertanyaan atau pernyataan tertulis kepada responden untuk menjawabnya (Sugiyono, 2014: 142).

Angket validasi media pembelajaran memiliki gradulasi pernyataan sangat positif sampai sangat negatif yang digunakan untuk mengukur indikator program yang berkaitan dengan kriteria pendidikan, tampilan dan kualitas teknis.

Angket motivasi belajar digunakan untuk mengetahui besar pengaruh penggunaan buku petunjuk praktikum berbantuan kearifan lokal bila dibandingkan dengan media konvensional.

Angket yang digunakan harus dilakukan uji validasi dan uji releabilitas. Dimana teknik analisis data untuk percobaan ini adalah teknik angket dan dokumentasi. Seperti kisi-kisi ngket motivasi dibawah ini pada tabel 1

TABEL 1

KISI-KISI ANGKET MOTIVASI BELAJAR SISWA

\begin{tabular}{|c|l|}
\hline No & \multicolumn{1}{|c|}{ Indikator } \\
\hline 1 & Perhatian \\
\hline 2 & Relevansi \\
\hline 3 & Kepercayaan diri \\
\hline 4 & Kepuasan \\
\hline
\end{tabular}

Skala pengukuran yang digunakan untuk mengukur validasi produk dan motivasi belajar siswa adalah skla likert yang memiliki gradulasi penilaian dari sangat positif sampai sangat negatif. Teknik skorsing dalam skala likert adalah sebagai berikut:
a. Sangat Setuju (Sangat Positif) diberi skor 5
b. Setuju (Positif) diberi skor 4
c. Kurang Setuju (Negatif) diberi skor 3 
d. Tidak Setuju (Sangat Negatif) diberi skor 2

e. Sangat Tidak Setuju (SangatNegatif) diberiskor 1

\section{a. Uji Validitas}

Untuk menghitung banyaknya pernyataan yang valid atau tidaknya dapat dihitung nilai validitas dengan rumus Pearson Product Moment adalah:

$r_{x y}=\frac{n \sum X_{i} Y_{i}-\left(\sum X_{i}\right) \cdot\left(\sum Y_{i}\right)}{\sqrt{\left\{n \sum X_{i}^{2}-\left(\sum X_{i}\right)^{2}\right\} \cdot\left\{n \cdot \sum Y_{i}^{2}-\left(\sum Y_{i}\right)^{2}\right\}}}$

(Riduwan, $2014: 73$ )

\section{b. Uji Reabilitas}

Uji reliabilitas dilakukan untuk mengetahui reliabilitas angket, (instrument) yang digunakan. Langkah-langkah mencari nilai reliabilitas sebagai berikut:

$r_{11}=\left(\frac{k}{k-1}\right)\left(1-\frac{\sum S_{i}}{S_{t}}\right)$

Selain itu perlu dicari nilai varians untuk menentukan reliabilitas angket motivasi belajar siswa menggunakan rumus sebagai berikut:

$S_{i}=\frac{\sum X_{i}^{2}-\frac{\left(\sum X_{i}\right)^{2}}{N}}{N}$

Nilai korelasi yang diperoleh dikonsultasikan ke tabel Product Moment dengan taraf $a=0,05$ atau $a$ $=0,01$. Jika harga $r_{\text {hitung }}>r_{\text {tabel }}$ maka reliable dan harga $r_{\text {hitung }}<r_{\text {tabel }}$ berarti tidak reliabel (Riduwan, 2014: 75).

\section{c. Motivasi belajar siswa}

Untuk menghitung angket tingkat motivasi siswa digunkan persamaan berikut:

TABEL 2

PENILAIAN SKALA 1-5 MOTIVASI BELAJAR SISWA

\begin{tabular}{|l|c|}
\hline \multicolumn{1}{|c|}{ Interval } & Skor \\
\hline$(\mathrm{M}+1,5 \mathrm{OS})<\mathrm{X}$ & A \\
\hline$(\mathrm{M}+0,5 \mathrm{OS})<\mathrm{X} \leq(\mathrm{M}+1,5 \mathrm{OS})$ & B \\
\hline$(\mathrm{M}-\mathrm{O}, 5 \mathrm{OS})<\mathrm{X} \leq(\mathrm{M}+0,5 \mathrm{OS})$ & $\mathrm{C}$ \\
\hline$(\mathrm{M}-1,5 \mathrm{OS})<\mathrm{X} \leq(\mathrm{M}-0,5 \mathrm{OS})$ & $\mathrm{D}$ \\
\hline $\mathrm{X} \leq(\mathrm{M}-1,5 \mathrm{OS})$ & $\mathrm{E}$ \\
\hline
\end{tabular}

(Azwar, 2015: 163)

Data motivasi belajar siswa diolah tiap pernyataan kemudian diolah berdasarkan indikator. Data perindikator setelah diolah maka motivasi belajar siswa dapat diketahui. Data motivasi belajar siswa dihitung dengan persamaan berikut:

$P(\%)=\left(\frac{n}{N}\right) x 100 \%$

Menghitung besarnya peningkatan motivasi belajar siswa dengan menggunakan rumus Hake:

gain $=\frac{S_{\text {post }} S_{\text {pre }}}{100-S_{\text {pre }}}$
Data hasil perhitungan angket motivasi sebelum dan sesudah siswa kemudian akan diiterpretasikan dengan menggunakan gain standar sebagai berikut:

TABEL 3

NILAI INDEKS GAIN STANDAR

\begin{tabular}{|c|c|}
\hline Nilai gain standar & Keterangan \\
\hline$\geq 0,7$ & Tinggi \\
\hline $0,7 \geq g \geq 0,3$ & Sedang \\
\hline$\leq 0,3$ & Rendah \\
\hline
\end{tabular}

Apabila media berupa buku petunjuk praktikum berbantuan kearifan lokal dapat meningkatkan motivasi belajar siswa, maka media berupa buku petunjuk praktikum dikatakan telah teruji keefektifannya

\section{d. Pengaruh Motivasi Belajar Siswa}

Untuk menentukan pengaruh motivasi belajar siswa terhadap buku petunjuk praktikum, terlebih dahulu dihitung nilai $r_{\text {hitung }}$ dengan rumus:

$$
r_{x y}=\frac{n \sum X_{i} Y_{i}-\left(\sum X_{i}\right) \cdot\left(\sum Y_{i}\right)}{\left.\sqrt{\left\{n \sum X_{i}^{2}-\left(\sum X_{i}\right)^{2}\right\}}\right\} \cdot\left\{n \cdot \sum Y_{i}^{2}-\left(\sum Y_{i}\right)^{2}\right\}}
$$

Selanjutnya dihitung Uji-t dengan rumus:

$$
t_{\text {hitung }}=\frac{r \sqrt{n-2}}{\sqrt{1-r^{2}}}
$$

\section{HASIL DAN PEMBAHASAN Metode Penelitian Tahap I}

1. Potensi dan Masalah

Berdasarkan hasil wawancara dengan guru fisika di MAN 2 Model Mataram, ditemukan adanya potensi yang dimiliki oleh siswa untuk melakukan praktikum pada mata pelajaran fisika akan tetapi adanya permasalahan yang mengakibatkan kurangnya motivasi belajar siswa yaitu metode pengajaran yang digunakkan oleh guru kurang efektif, kurangnya menggunakan media pembelajaran sebagai media tambahan untuk menarik minat belajar siswa, dan kurang tersedianya buku pelajaran serta tidak adanya praktikum bagi masingmasing siswa.

Oleh karena kurang tersedianya buku pelajaran dan tidak adanya buku praktikum bagi masing-masing siswa sehingga pada setiap pelajaran fisika wajib mencatat untuk mengejar materi tanpa adanya praktikum. Permasalahan tersebut harus diatasi dan diperlukan suatu cara, bukan hanya strategi dan model pembelajaran yang cocok digunakan oleh guru selama proses pembelajran, namun yang paling penting adalah media pembelajaran tambahan dan praktikum yang dapat membantu siswa dalam belajar sehingga tidak perlu mencatat semua materi setiap pertemuan. Salah satu media pembelajaran yang tepat dan sesuai untuk meningkatkan motivasi belajar siswa adalah Buku Petunjuk Praktikum. 
2. Mengumpulkan Informasi

Pengumpulan informasi dilakukan dengan observasi sehingga diperoleh informasi bahwa siswa memiliki motivasi belajar siswa kelas XI di MAN 2 Model Mataram masih kurang. Observasi dilakukan dengan menanyakan permasalahan pada guru yang mengajar dan melakukan pengamatan dalam kegiatan pembelajaran dikelas.

\section{Desain Produk}

Berdasarkan kondisi yang telah ada di sekolah, dapat diketahui bahwa dalam pelaksanaan pembelajaran media buku yang praktis dan praktikum sangat dibutuhkan oleh siswa. Buku pelajaran disekolah yang digunakan guru untuk mengajar masih kurang membantu untuk meningkatkan motivasi belajar siswa. Buku pelajaran yang digunakan dalam pembelajaran memiliki pembahasan materi yang panjang sehingga siswa cepat merasa bosan dalam membacanya kemudian sulit memahami konsep dalam buku tersebut. Serta buku pelajaran yang digunakan tersebut tidak memiliki praktikum yang bertujuan untuk meningkatkan motivasi belajar siswa. Dengan demikian, maka diperlukan media yang mampu menigkatkan motivasi belajar siswa.

Berdasarkan kondisi yang telah ada disekolah, peneliti mengembangkan Buku Petunjuk Praktikum yang terdiri dari cover Buku Petunjuk Praktikum, materi singkat, kegiatan praktikum, soal dan kata motivasi. Buku Petunjuk Praktikum yang dibuat memiliki jenis dan ukuran tulisan yang mudah dibaca. Desain awal produk dikerjakan dengan menggunakan program microsoft office publizer 2007 kemudian dicetak dengan menggunakan kertas foto $A 4230$ gram.3

\section{Hasil Validasi Ahli}

Kegiatan validasi Buku Petunjuk Praktikum dilakukan oleh para ahli dengan mengisi angket yang berisi 19 pernyataan yang terdiri dari kriteria pendidikan, kriteria tampilan, dan kualitas teknis. Buku Petunjuk Praktikum divalidasi oleh 4 ahli yang dianggap respresentatif dan berpengalaman mengajar materi Fisika dan Ahli media. Angket diisi oleh ahli yang terdiri dari 3 orang dosen dan 1 guru mata pelajaran FISIKA di MAN 2 Model Mataram. Hasil validasi Buku Petunjuk Praktikum adalah sebagai berikut:

\section{a. Ahli I}

Sesuai dengan hasil pengisian angket dari Bapak Zulkarnain, M.Si selaku ahli I, bahwa item yang paling tinggi diperoleh pada skala 5 (sangat setuju), dimana pengisian angket tertinggi untuk kriteria pendidikan terdapat pada item nomor 4, 5 dan 6 , kriteria tampilan terdapat pada item nomor 3 dengan pernyataan tampilan cover buku praktikum menarik dan gambar sesuai dengan cakupan isinya. Serta pada kriteria teknis terdapat pada item nomor 1,2,3,5 dan 6. Terendah pada skala 3 (kurang setuju). Untuk kriteria tampilan terdapat pada item nomor
2 dan 6, dengan pernyataan pada angket bahasa yang digunakan dalam penyusunan materi buku petunjuk praktikum sesuai aturan tata bahasa Indonesia yang benar dan penyusunan kalimat dalam pengembangan buku petunjuk praktikum telah mengikuti susunan bahasa Indonesia yang benar. Berdasarkan hasil pengolahan data menggunakan interval diperoleh untuk kualitas kriteria pendidikan sangat baik, kriteria tampilan baik dan kriteria teknis sangat baik, sehingga disimpulkan bahwa petunjuk praktikum berbentuk buku petunjuk praktikum layak untuk digunakan dan ahli I menyarankan revisi pada warna, font dan garis pada tabel.

b. Ahli II

Pengisian angket dari Ary Purmadi, M.Pd selaku ahli II diperoleh pengisian angket tertinggi berada di skala 5 (sangat setuju) yaitu pada kriteria pendidikan nomor item 2 dengan pernyataan uraian contoh soal dalam buku petunjuk praktikum mempermudah dan pemahaman siswa terhadap materi gelombang dan bunyi, pada kriteria tampilan nomot item 3 denga pernyataan tampilan cover buku petunjuk praktikum menarik dan gambar sesuai dengan cakupan isinya dan pada kriteria teknis nomor item 7 denga peenyataan pengembangan buku petunjuk praktikum ini sangat praktis dan mudah dibawa kemana-mana. Pengolahan datanya menggunakan interval berada pada kriteria untuk kualitas pendidikan sangat baik, tampilan sangat baik dan teknis sangat baik.

c. Ahli III

Pengisian angket dari Ibu Linda Sekar Utami, S.Pd., M.Pfis selaku ahli III diperoleh di kriteria pendidikan pada item nomor $1,3,4$, dan 6 , kriteria tampilan item nomor 1, kriteria teknis item nomor 1, 2, 3, dan 6 sama-sama berada pada skala 5 yaitu sangat setuju. Sedangkan pengisian angket terendah rata-rata berada pada skala 3 yaitu kurang setuju yang berada pada kriteria tampilan item nomor 2 dan 6 dan pada kriteria teknis terdapat item nomor 7. Dari hasil pengisian angket ahli III untuk kualitas pendidikan, kualitas tampilan dan kualitas teknis diperoleh hasil pengolahan datanya menggunakan interval berada pada kriteria sangat baik, kriteria tampilan Baik dan kriteria teknis Sangat Baik. Ahli III merekomendasikan perbaikkan revisi pada bagian bahasa yang digunakan dan penyesuaian warna.

\section{d. Praktisi}

Hasil pengisian angket dari Khusnal Khotimah, S.Pd., M.Pd selaku praktisi bahwa pengisian angket tertinggi rata-rata berada pada skala 5 (sangat setuju) terdapat pada kriteria pendidikan dan kualitas teknis. Sedangkan pengisian angket terendah berada pada skala 3 (kurang setuju) yaitu 
item 3 dikriteria teknis pada nomor item 7. Dari hasil pengisian angket praktisi untuk kualitas pendidikan, kualitas tampilan dan kualitas teknis diperoleh hasil pengolahan datanya menggunakan interval berada pada kriteria sangat baik pada kriteria pendidikan dan sangat baik pada kriteria tampilan dan teknis dimana berdasarkan praktisi tidak ada revisi pada produk.

Persentase hasil perhitugan validasi media Ahli I, Ahli II, Ahli III, dan Praktisi.

\section{Revisi produk}

Hasil validasi produk yang telah dilakukan menunjukkan bahwa media petunjuk praktikum berbentuk buku petunjuk praktikum harus dilakukan revisi pada bagian tertentu yaitu proporsional gambar, ukuran tulisan dan bahasa Indonesia yang digunakan.

\subsubsection{Metode Penelitian Tahap II}

4.1.2.1 Hasil uji validitas angket

Media pembelajaran Petunjuk praktikum berbentuk buku petunjuk praktikum ini selanjutnya diterapkan untuk meningkatkan motivasi belajar siswa pada kelompok kecil yaitu kelas XI MAN 2 Model Mataram. Besar motivasi belajar siswa dapat diukur dengan memberikan angket motivasi belajar kepada siswa. Ada beberapa bentuk aspek motivasi belajar yang ingin diketahui dalam penelitian ini antara lain, disiplin, tanggung jawab, kreatif, komunikatif dan teliti.

Uji validitas dilakukan pada pernyataan angket dengan menggunakan persamaan korelasi product moment. Hasil uji validitas angket motivasi belajar adalah sebagai berikut:

Tabel 4.1 Hasil Perhitungan Validitas Pernyataan Angket

\begin{tabular}{|c|c|c|}
\hline Jumlah Pernyataan & Valid & Tidak Valid \\
\hline 30 & 14 & 16 \\
\hline
\end{tabular}

4.1.2.2 Hasil Uji Reliabelitas Angket

Pernyataan pada angket diuji keajengan/keandalannya dengan menggunakan persamaan alpha cronbach. Hasil uji reliabelitas pada pernyataan dapat dilihat pada tabel berikut ini:

Tabel 4.2 Hasil Perhitungan Reliabelitas Pernyataan Angket

\begin{tabular}{|c|c|c|}
\hline $\begin{array}{c}\text { Jumlah } \\
\text { Pernyataan }\end{array}$ & Reliabel & Tidak Reliabel \\
\hline 30 & 14 & 16 \\
\hline
\end{tabular}

Pengolahan validitas dan reliabilitas pernyataan pada angket motivasi siswa selengkapnya dapat dilihat pada lampiran 12.

4.1.2.3 Hasil uji coba

Uji kelompok yang digunakan adalah kelas XI MAN 2 Model Mataram dengan menggunakan angket motivasi yang sudah valid kemudian diberikan kepada siswa sebelum pembelajaran dimulai. Kegiatan pengisian angket dapat dilakukan selama 10 menit pada pertemuan pertama sebelum kegiatan pembelajaran dan pada pertemuan terakhir. Masing-masing kelompok mendapatkan 1 buku petunjuk praktikum.

Perhitungan motivasi belajar siswa dilakukan pada setiap bentuk aspek atau indikator motivasi. Hasil angket motivasi kemudian diolah dengan menggunakan langkah-langkah yang dilakukan. Berdasarkan hasil perhitungan dalam penelitian yang dilakukan, maka dapat dilihat peningkatan motivasi belajar pada siswa.

\subsection{Pembahasan}

\subsubsection{Metode Penelitian Tahap I}

\subsubsection{Potensi dan Masalah}

Dari hasil dari kegiatan observasi yang dilakukan terhadap siswa kelas XI MAN 2 Model Mataram menunjukan bahwa potensi yang ditemukan dalam penelitian ini adalah Buku petunjuk praktikum sebagai pegangan siswa untuk praktikum dan didalam kelas selama kegiatan pembelajaran dengan masalah yang paling utama adalah kurangnya motivasi belajar siswa kelas XI MAN 2 Model Mataram mata pelajaran Fisika. Rendahnya motivasi belajar siswa ini ditunjukan dengan jarangnya siswa mengajukan pertanyaan, malasnya peserta didik mencatat materi pelajaran dan kurangnya respon terhadap pertanyaan yang disampaikan oleh guru. Salah satu penyebabnya adalah kurang buku pegangan siswa untuk belajar di rumah dan siswa harus mencatat dan memfoto copy materi untuk proses belajar mengajar dikelas.

Berdasarkan potensi yang ditemukan ini, peneliti bermaksud mengembangkan media berupa Petunjuk praktikum berbentuk buku petunjuk praktikum. Buku petunjuk praktikum Fisika pernah diterapkan disekolah lain tapi belum pernah dikembangkan di MAN 2 Model Mataram. Petunjuk praktikum berbentuk buku petunjuk praktikum yang peneliti kembangkan memiliki pendidikan berkarakter, serta bentuk evaluasi yang menarik.

Media pembelajaran Petunjuk praktikum berbentuk buku petunjuk praktikum yang akan dihasilkan yaitu terdiri dari cover buku petunjuk praktikum, kata pengantar, daftar isi, peta konsep materi, kegiatan praktikum dan evaluasi. Petunjuk praktikum berbentuk buku petunjuk praktikum yang dibuat memiliki jenis dan ukuran tulisan yang mudah dibaca serta konsistensi penomoran pada halamannya. Desain awal produk dikerjakan dengan menggunakan program microsoft office publizer 2007 kemudian dicetak dengan menggunakan kertas $A_{4} 80$ gram untuk mengukur motivasi belajar siswa. Berbeda dengan penelitian yang telah dilakukan oleh Styosari (2013), yang diukur adalah minat baca siswa, dan tidak memiliki evaluasi yang menarik dan LKS. Desain awal Petunjuk praktikum berbentuk buku petunjuk praktikum dapat dilihat pada lampiran 3. Berbeda dengan penelitian yang telah dilakukan oleh Styosari (2013)

4.2.1.2 Desain Awal Produk 
Kondisi pada potensi dan masalah yang ada mendorong peneliti untuk mengembangkan Petunjuk praktikum berbentuk buku petunjuk praktikum untuk membantu proses belajar mengajar. Petunjuk praktikum berbentuk buku petunjuk praktikum memiliki kelebihan antara lain dapat memotivasi siswa dalam proses pembelajaran bahkan diluar jam pelajaran karena Petunjuk praktikum berbentuk buku petunjuk praktikum ini sangat mudah dibawa kemana-mana. Selain itu juga Petunjuk praktikum berbentuk buku petunjuk praktikum ini memiliki kombinasi warna yang bervariasi dan gambar-gambar menarik minat baca pada siswa.

\subsubsection{Hasil Validasi Ahli}

Media pembelajaran yang telah di desain divalidasi oleh ahli sebelum diuji pada kelompok kecil. Validasi Petunjuk praktikum berbentuk buku petunjuk praktikum dilakukan oleh 3 ahli 1 praktisi.

Hasil validasi dari ahli praktisi mengatakan tidak ada revisi terhadap produk karena sudah dikatakan layak untuk digunakan. Hasil yang berbeda diperoleh dari ahli I, II dan III merekomendasikan perbaikkan mengenai tabel, perpaduan warna, jenis tulisan dan gambar. Hasil validasi ahli menunjukkan bahwa media pembelajaran Petunjuk praktikum berbentuk buku petunjuk praktikum layak digunakan dalam pembelajaran setelah melakukan revisi.

\subsubsection{Revisi Produk}

Revisi produk Petunjuk praktikum berbentuk buku petunjuk praktikum dilakukan pada pemberian garis pada tabel edisi kedua, memberikan kombinasi warna dan tulisan yang sesuai sehingga mudah untuk dibaca dan jenis tulisan yang digunakan disesuaikan dengan ukuran tulisan..

\subsubsection{Metode Penelitian Tahap II}

Penggunaan media pembelajaran Petunjuk praktikum berbentuk buku petunjuk praktikum di MAN 2 Model Mataram untuk mneingkatkan motivasi belajar siswa pada mata pelajaran FISIKA materi gelombang dan bunyi. Sebelum menerapkan media pembelajaran Petunjuk praktikum berbentuk buku petunjuk praktikum, siswa mengisi angket motivasi belajar yang sebelumnya telah divalidasi. Angket yang telah diisi oleh siswa kemudian diolah untuk mengetahui besar motivasi siswa.

Motivasi belajar siswa diolah berdasarkan indikator masing-masing. Jumlah semua indikator adalah 4. Untuk indikator perhatian jumlahnya ada 1 dimana sebelum menggunakan Petunjuk praktikum berbentuk buku petunjuk praktikum $48 \%$ dan setelah penerapan meningkat menjadi $74 \%$. Kriteria peningkatan motivasi dikorelasikan dengan kriteria gaindimana diperoleh hasil peningkatan motivasi belajar siswa sebesar 0,50 dan berada pada kategori sedang. Aspek motivasi belajar yang kedua adalah relevansi dengan jumlah masing-masing 6 item sebelum dan sesudah dimana sebelum penerapan Petunjuk praktikum berbentuk buku petunjuk praktikum 49,5\% dan setelah penerapan meningkat menjadi $75,6 \%$, dengan nilai gain sebenar 0,53. Dan aspek motivasi belajar yang ketiga adalah kepercayaan diri, sebelum penggunaan media besar motivasi siswa adalah $43,6 \%$ dan setelahnya menjadi $75 \%$ dengan nilai gain $0,55 \%$ untuk jumlah item soal 3. Dan yang ke empat adalah kepuasan dengan banyak 4 item soal, sebelum menggunakan Petunjuk praktikum berbentuk buku petunjuk praktikum sebesar 49,5\% dan setelah menggunakan menjadi $75 \%$ dengan nilai gain $0,50 \%$.

Dalam pengukuran motivasi belajar siswa digunakan teknik analisis data berupa data kuantitatif, yang diperoleh peningkatan dengan menggunakan normalisasi gain (gain) untuk motivasi belajar berupa perhatian 0,50 dengan kriteria sedang, motivasi belajar relevansi 0,53 dengan kriteria sedang, motivasi belajar kepercayaan diri 0,55 dengan kriteria sedang, dan motivasi belajar kepuasan 0,50 dengan kriteria sedang Peningkatan motivasi belajar secara klasikal juga berada pada kriteria sedang dengan normalisasi gain sebesar 0.52. Dengan demikian, hasil penelitian terhadap motivasi belajar siswa secara klasikal mengalami peningkatan motivasi belajar berada dalam kategori sedang.

\section{SIMPULAN DAN SARAN}

Berdasarkan penelitian yang telah dilaksanakan dapat disimpulkan bahwa media pembelajaran berupa Petunjuk praktikum berbentuk buku petunjuk praktikum dapat:

1. Teruji kevalidannya baik dari segi ahli media maupun materi, dimana untuk kriteria pendidikan semua ahli memberikan nilai A, untuk kriteria tampilan 2 ahli memberikan nilai A dan nilai B dari 2 ahli yang lain, serta untuk kriteria teknis semua ahli memberikan nilai A.

2. Proses pembelajran berjalan dengan lancar, karena respon siswa yang baik terhadap buku petunjuk praktikum fisika yang menjadi sumber belajar.

3. Teruji keefektifannya karena mampu meningkatkan motivasi belajar siswa kelas XI MAN 2 Model Mataram pada materi gelombang dan bunyi. Dimana diperoleh gain untuk motivasi belajar berupa perhatian 0,50 dengan kriteria sedang, motivasi belajar berupa relevansi 0,53 dengan kriteria sedang, motivasi belajar berupa kepercayaan diri 0,55 dengan kriteria sedang dan yang terakhir motivasi belajar berupa kepuasan 0,50 dengan kriteria sedang. Sedangkan Peningkatan motivasi belajar secara klasikal juga berada pada kriteria sedang dengan normalisasi gain sebesar 0,52 .

Berdasarkan penelitiaan yang telah dilakukan, maka diberikan beberapa saran bagi peneliti selanjutnya yaitu:

1. Petunjuk praktikum berbentuk buku petunjuk praktikum yang dikembangkan dapat digunakan dengan baik, namun masih 
memiliki kekurangan baik dari segi pendidikan, tampilan, dan kualitas teknis. Hal ini dapat dijadikan pertimbangan bagi peneliti selanjutnya untuk mengembangkan media pembelajaran yang lebih sempurna lagi.

2. Petunjuk praktikum berbentuk buku petunjuk praktikum ini dapat dikembangkan untuk semua materi Fisika untuk materi yang berbeda.

3. Penelitian ini dilaksanakan sampai pada tahap uji coba kelompok kecil. Oleh karena itu diharapkan pada penelitian selanjutnya dilaksanakan sampai pada tahap penyebaran.

\section{UCAPAN TERIMA KASIH}

Penulis mengucapkan terima kasih kepada dosen pembimbing, dosen fisika, guru fisika serta siswa kelas XI MIA B MAN 2 Model Kota Mataram yang telah membantu dalam penelitian ini.

\section{DAFTAR RUJUKAN}

[1] Albab, M. Nourma. 2014. Pengembangan Modul Fisika Berbasis Kearifan Lokal Mata Materi Hukum Newton Untuk Siswa SMA N 1 Sento Kelas X Bulon Progo. Skripsi. Universitas Islam Negeri Sunan Kali Jaga yogyakarta.

[2] Azizahwati, dkk. 2015. Pengembangan Modul Pembelajaran Fisika SMA Berbasis Kearifan Lokal untuk Meningkatkan Hasil Belajar Siswa. Jurnal Pendidikan Fisika, Prosiding Pertemuan Ilmiah XXIX HFI Jateng \& DIY ISSN : o853-0823. Diakses pada tanggal o9 februari 2017.

[3] Azwar, Saifuddin. 2015. Tes Prestasi. Yogyakarta: Pustaka Pelajar.

[4] Ekajati.2013. Fisika Dasar Edisis II. Andi. Yogyakarta.

[5] Emzir. 2014. Metode Penelitian Pendidikan Kuantitatif \& Kualitatif Edisi Revisi. Jakarta: PT Raja Grafindo Persada.

[6] Giancoli, 2001. Fisika Edisi Kelima Jilid I. Jakarta: PT. Gelora Aksara Pratama

[7] Halliday David, 2003. Dasar-Dasar Fisika Jilid I. Tanggerang: Binarupa Aksara Publisher.

[8] Hake, R.R. (1998). Interactive-engagement versustraditional methods: A six-thousand-student survey of mechanics test data for introductory physics courses. American Journal of Physics 66, 64 (1998). 10.1119/1.18809

[9] Martawijaya, M. Agus. 2014. Buku Fisika Peserta Didik Berbasis Kearifan Lokal Untuk Meningkatkan Karakter Dan Ketuntasan Belajar. Jurnal Sains dan Pendidikan Fisika. Jilid 10, Nomor 3, Desember 2014.

[10] Nurhidayati. 2009. Pengembangan penuntut pratikum fisika dasar I berbasis quided inquiry untuk meningkatkan kemampuan berpikir kritis mahasiswa secara kelompok kecil dan kelompok besar. Skripsi. Universitas negeri Jakarta.

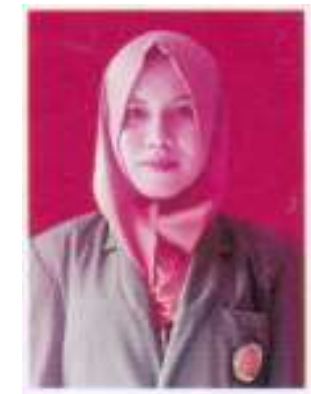

\section{PROFIL PENULIS}

Nama Penulis adalah Marha. Lahir Kale'o, 02 Agustus 1994. Sekolah Dasar dimulai dari SDN Inpres Kale'o pada tahun 2003-2008. Setelah itu, dilanjutkan di SMPN 2 LAMBU pada tahun 2008-2010 dan terakhir di SMAN 2 LAMBU pada tahun 20102013 di jurusan IPA. Kemudian penulis dilanjutkan di Universitas Muhammadiyah Mataram dalam program pendidikan Fisika Fakultas keguruan dan Ilmu Pendidikan (FKIP) pada tahun 2013. Saran dan kritik atau peningkatan penelitian ini yang bias dikirim melalui e-mail di : marhapian14@gmail.com 